22.2

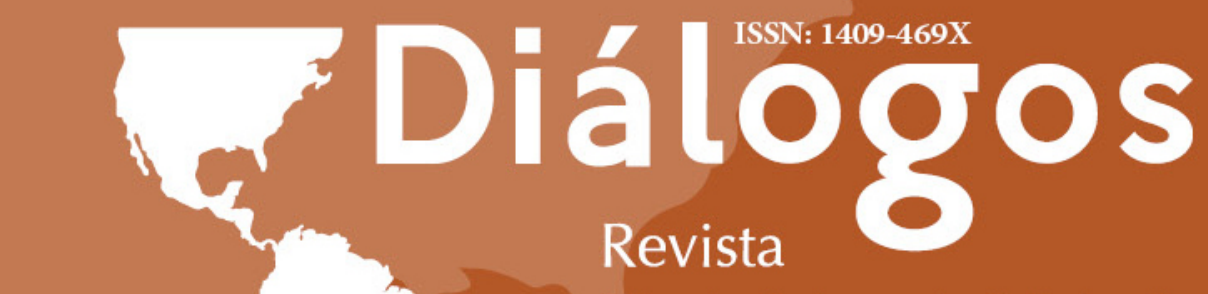

Electrónica de Historia

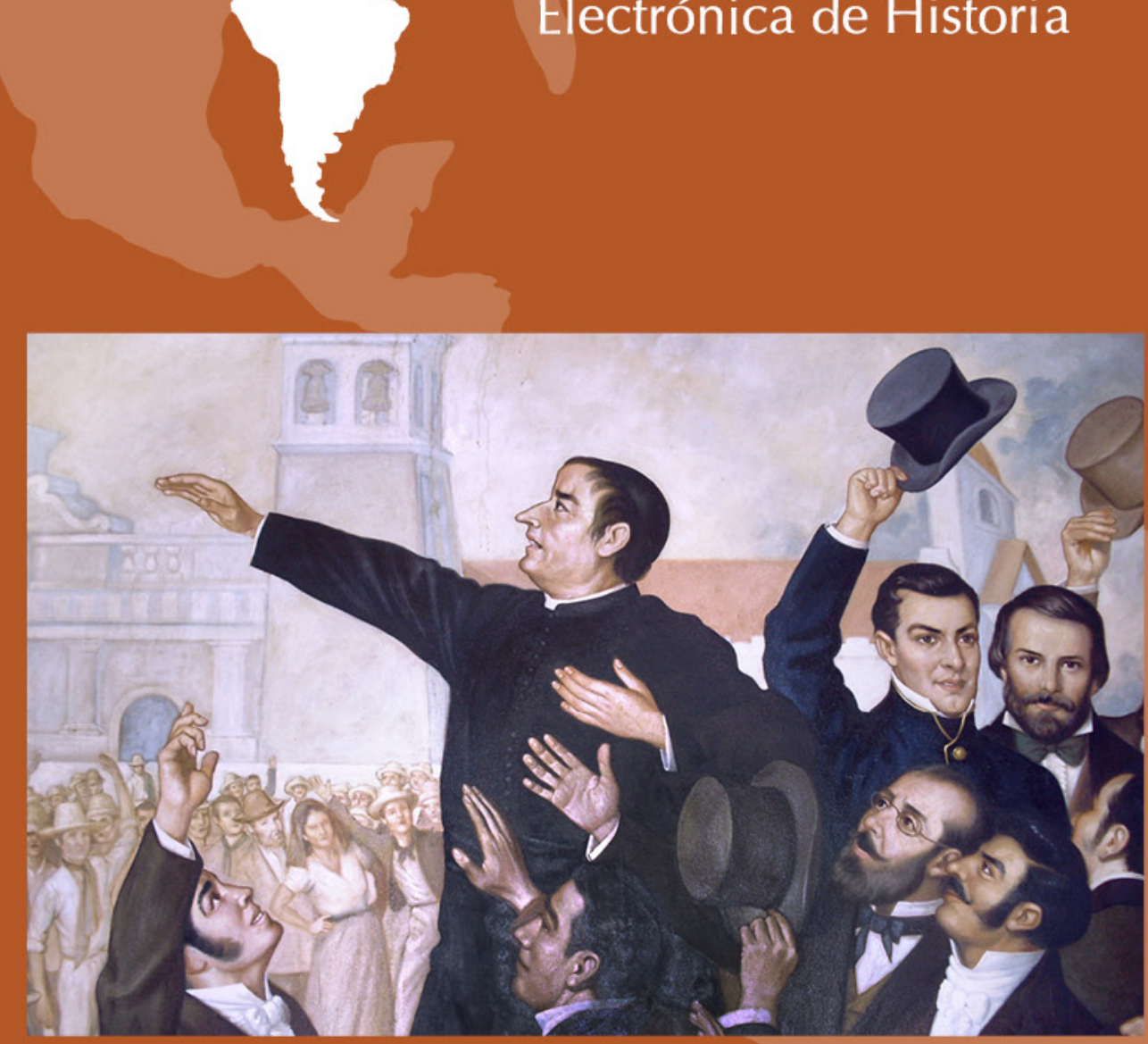

Centro de Investigaciones Históricas de América Central. Universidad de Costa Rica

\title{
Julio-diciembre 2021
}

url: http://revistas.ucr.ac.cr/index.php/dialogos/index

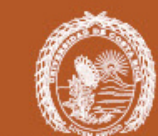

UNIVERSIDAD DE

COSTARICA

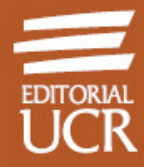


Pobreza y desigualdad

social en la narrativa costarricense:

1890-1950

Ruth Cubillo Paniagua

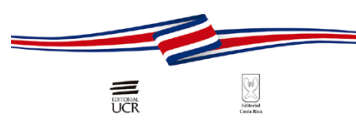

COMENTARIO DEL LIBRO:

NOMBRE AUTOR

Cubillo Paniagua, R. (2020). Pobreza y

desigualdad social en la narrativa costarricense:

1890-1950. San José: Editorial Universidad

de Costa Rica/Editorial Costa Rica.

David Díaz Arias

Ruth Cubillo Paniagua (San José, 1970) es una destacada estudiosa de la literatura costarricense a quien se le deben varios importantes trabajos en los que ha explorado, con profundidad, la forma en que se crearon significados e imágenes de las mujeres en diversas narrativas ficcionales tanto en Costa Rica, como en Centroamérica, el Caribe y en España. La materia prima para esos análisis ha sido diversa: revistas literarias, cuentos, novelas, periódicos, obras dramatúrgicas, películas y documentales. Basta echar un vistazo a sus_libros, para advertir las dimensiones de sus contribuciones.

Su primer libro Mujeres e identidades: las escritoras del repertorio americano (1919-1959), publicado en 2001, estudia las imágenes de las mujeres creadas por autoras y autores en la icónica revista de Joaquín García Monge, para mostrar cómo se construyeron esas identidades en los conceptos de "la mujer madre", "la mujer y la política" y "la mujer autora". En su segundo libro, Mujeres ensayistas e intelectuales de vanguardia en la Costa Rica de la primera mitad del siglo XX, publicado en 2011, Cubillo exploró la producción de Ángela Acuña, María Isabel Carvajal, Emma Gamboa, Luisa González, Eunice Odio, Yolanda Oreamuno, Emilia Prieto y Lilia Ramos, a quienes evaluó como mujeres rebeldes que lograron hacer temblar los cimientos de la cultura patriarcal costarricense de las primeras décadas del siglo pasado. En su tercer libro, Novelistas españolas del siglo de oro, aparecido en 2014, Cubillo realizó una brillante aproximación a la obra de la escritora española Mariana de Carvajal y Saavedra para determinar las conductas que, en las novelas cortas del siglo de oro, se esperaban de las mujeres. Y en su cuarta obra, escrita en colaboración con Olga Marta Mesén Sequeira, se abordó la 
dramaturgia costarricense del periodo 1950-1980, también a partir de una lectura crítica desde la perspectiva de género.

He indicado lo anterior no solo para rastrear la importante obra de la autora, sino para anotar un significativo rompimiento con esos trabajos, el cual se presenta en el libro que comentamos. Desde el título, se observa que Cubillo varía el punto de lectura de su corpus para destilarlo a partir de una nueva pregunta: los escritores costarricenses del periodo 1890-1950 ¿se interesaron por visualizar la pobreza y la desigualdad social del país en las obras que escribieron? Si fue así, ¿cómo lo hicieron? ¿Qué conductas modelaron en los pobres? ¿Se adentraron en los intersticios que producían esas desigualdades sociales en Costa Rica? ¿Ofrecieron salidas de escape a los conflictos generados por esa pobreza? A pesar de ese cambio en su aproximación, Cubillo no renuncia a observa, cada vez que puede, las tremendas disparidades generadas por el Patriarcado, las cuales sirven para erigir desigualdades sociales más pronunciadas entre hombres y mujeres.

Cubillo también es muy precisa para indicar que sus intereses en este libro se centran en las desigualdades socioeconómicas, por lo que resalta el concepto de pobreza es geo-histórico (p. xvii), es decir, que responde a una realidad histórica precisa y a un imaginario cultural localizado territorialmente. En esto, la autora se posiciona en la discusión sobre el texto y su contexto, para resaltar que la literatura de ficción no es ajena a sus productores ni a la temporalidad en la que la crea. Por eso, subraya lo fundamental de "establecer un diálogo entre textos literarios y contexto socio-histórico", pues "la literatura es un producto social, atravesado por muchos y diversos discursos sociales" (p. 182). Esa constatación lleva a la autora a reconstruir el mundo histórico en que escribieron las tres generaciones de escritores que estudia y, a la vez, encontrar vínculos entre las historias individuales de esos literatos y sus posibilidades de visualizar las diversas dimensiones de la pobreza y de los pobres de la Costa Rica en que vivieron.

El libro está dividido en tres grandes capítulos. El primero profundiza en las obras de los autores de la llamada generación del Olimpo, a quienes Cubillo divide en dos: los olímpicos liberales y los olímpicos nacionalistas. Todos los creadores de esta generación fueron hombres, procedentes de familias acomodadas, con múltiples experiencias de vida en el extranjero, animados en sus diferencias de estilo por considerar viable o inviable la producción de literatura nacional que reprodujera el lenguaje popular. Esa diferencia, resaltada por múltiples estudiosos a través del tiempo, no aparece retratada en la permanente invisibilidad de las desigualdades sociales que Cubillo observa en las obras de estos autores. De hecho, la autora resalta que el tema de la pobreza a veces ni siquiera se sugiere en las obras que estudia y se pregunta a qué se debe esa ausencia. En términos históricos no tiene justificación, pues la autora recrea la Costa Rica de finales del siglo XIX y principios del siglo XX como llena de injusticias económicas y plagada de tremendas desigualdades sociales. ¿Por qué entonces tal ceguera para ver a los pobres? Cubillo ofrece una respuesta múltiple: los autores olímpicos, no importa si eran liberales o nacionalistas, 
representaron un mundo en el que los pobres no eran sujetos de importancia para la creación literaria y, si aparecían, lo hacían solo como sujetos inactivos, como posesiones de los protagonistas que vivían en ambientes desprovistos de necesidades sociales. La pobreza, cuando se fue invitada a esa obras, se atendió como un mal endémico sin ninguna posible cura definitiva, pues solo se podía aliviar con la caridad. Cubillo también resalta la profunda melancolía que se observa en esa generación con respecto a la oposición pasado-presente: para aquellos escritores, Costa Rica estaba en un punto de quiebre con un pasado recreado como puro, lleno de tradiciones y costumbres, con señorones y señoronas y desprovisto de luchas sociales, frente a un presente que iba perdiendo esos "valores" y personajes, amenazado por el extranjero y por la aparición de grupos que pervertían la armonía social. Pero la autora también indica: "conviene señalar que al tiempo que estos intelectuales liberales percibían la pobreza de esa forma, en su faceta de políticos liberales generaron políticas concretas para enfrentar ese problema social”. Así, Cubillo muestra cómo, a la par que se creaban esas ficciones de un mundo sin clases y sin desgarres sociales y a tono con la visión idílica del pasado en que se fundaba la identidad nacional, se procedía también a emitir políticas públicas que sirvieran para aliviar la forma en que las diferencias socio-económicas podían alterar la paz social del país. En sentido estricto, Cubillo descubre el sintagma nominal que dio origen a un elemento determinante del discurso social y nacionalista costarricense: que Costa Rica es un país sin grandes diferencias sociales. Este hallazgo me parece capital.

En el segundo capítulo, la autora se adentra en el análisis de la llamada "nueva intelectualidad" o "generación radical", que a principios del siglo XX se abocó a enfrentar en diversas formas la narrativa del Olimpo. Nuevamente, Cubillo descubre que la experiencia de vida de estos autores les permite avanzar dos pasos con respecto a la percepción de la pobreza, pues_sus historias personales tenían raíces en familias pobres, a veces rurales, y su empeño personal con asistencia de becas del Estado les había permitido una cierta movilidad social. Justamente en esas experiencias, la autora demuestra que estos literatos_disminuyeron el distanciamiento hacia los pobres en sus obras, hasta casi desaparecerlo, y ofrecieron la educación y asistencia del Estado a partir de políticas concretas, como las salidas al grave problema social de la desigualdad. Cubillo encuentra, entonces, no solo una "nueva intelectualidad" sino una nueva sensibilidad, tanto en términos políticos como socio-culturales y desvela otro significante_del discurso de movilidad social costarricense: el de la educación como herramienta. Con esta generación de escritores también comienza otra norma discursiva con respecto a Costa Rica: la de concentrarse en las experiencias campesinas, en lugar de las urbanas. Cubillo demuestra que las obras estudiadas develan un campo trazado por desigualdades, que precisan de ser atendidas. Al estudiar a Carmen Lyra, la autora insiste en eso y expone que ya en su obra hay un causante claro de desigualdad: la concentración en las clases altas de los beneficios del modelo de desarrollo agrario. La literatura, en esta lectura de Cubillo, se presenta 
como antesala de la política, lo cual coloca los estudios literarios en otro nivel en la discusión pública. Me parece fascinante ese posicionamiento.

El tercer capítulo está dedicado a la generación del 40. Estos autores avanzaron más en la identificación de la pobreza y sus causas, pero también tuvieron más imaginación para plantear posibles salidas a las desigualdades sociales. Cubillo anota que, con modos distintos de escritura ficcional y diferentes estrategias textuales, esos autores no perdieron de vista su propósito de denunciar las desigualdades sociales y lograron incorporar personajes antes desaparecidos, espacios geográficos ignorados y, con eso, afirmaron un compromiso político con su escritura (p. 190). La autora señala: "la literatura de la generación del 40 se convierte en una práctica social concienciadora y, en muchos sentidos, educativa o formativa, pues se propone lograr que el proletariado conozca sus derechos civiles y laborales, y que aprenda a defenderlos" (p. 191). Cubillo descubre una asociación directa entre los contenidos fundamentales del Programa Mínimo del Partido Comunista de Costa Rica y las temáticas, propuestas y denuncias que los escritores de esta generación expusieron en sus obras de ficción. Aparecen en esta generación dos vértices opuestos en el estilo de creación: uno, bien representado por Carlos Luis Fallas Sibaja, autor proletario que retrataba en sus obras la realidad tal cual la percibía; y el otro vértice, expuesto por Joaquín Gutiérrez, autor que intentó innovar en el canon literario y literaturizar la literatura costarricense, sin dejar de lado la denuncia social. Ciertamente, como lo deja en claro la autora, la novela La ruta de su evasión de Yolanda Oreamuno ya no estaba en ninguno de esos vértices, pues rompió de tajo con ellos al construir una literatura intimista y psicológica. Ahora bien, la salida que estos autores encontraron a la pobreza radicó en alcanzar una conciencia social que les permitiera asaltar las desigualdades a partir de una intervención en sus raíces, por lo que propusieron ya no solo políticas de Estado, sino cambiar el Estado desde sus entrañas.

Por lo indicado, este nuevo libro de Ruth Cubillo Paniagua representa una ruptura en los estudios literarios costarricenses. Su contribución no radica solo en el rompimiento del punto de lectura de la ficción producida entre 1890 y 1950 , sino en que ese posicionamiento le permite desentrañar las vías legitimatorias de la desigualdad social en Costa Rica y las estrategias con que la literatura contribuyó a recrear la particularidad costarricense en ese mundo desigual. Cubillo, además, reposiciona los estudios literarios para advertir en ellos dos elementos centrales que pudieron repercutir en políticas públicas determinadas: por un lado, una sensibilidad aguzada y cambiante sobre el tema de la pobreza que hizo a los autores transformar sus acercamientos para denunciarla y, a la vez, redimir la culpa nacional sobre ella y, por el otro lado, gracias a esa nueva sensibilidad literaria, la literatura actuó como antesala de la política. Con eso, Cubillo responde directa y contundentemente a quienes preguntan: bueno, ¿y para qué sirve la literatura además de entretener?

Este libro de Cubillo es, además, fundamental para la Costa Rica de la actualidad. La desigualdad es uno de los problemas que más aquejan ahora al país, pero casi no se le presta atención ni está en la agenda inmediata de la política o la prensa. 
Ya a mediados del 2018 se confirmó una tendencia que se acentuó en la era más radical de medidas neoliberales (1990s-2000s) y post-TLC (2007-presente): que el país ha subido en la medición del coeficiente Gini y que ahora está en el "topten" de los países más desiguales del mundo, junto con Sudáfrica, Haití, Honduras, Colombia, Brasil, Panamá, Chile, Ruanda y México. En Costa Rica, la pobreza se había mantenido en $20 \%$, pero con una creciente desigualdad que ponía al $10 \%$ más rico de la población a años luz de ese $20 \%$ pobre. Las mujeres son las que tienen un peor lugar en la desigualdad, porque reciben menos paga por los mismos trabajos y porque se concentra en ellas la atención de los adultos mayores y los niños y niñas y las labores domésticas. Ahora, de cara al bicentenario, nuestro país experimenta el mayor porcentaje histórico de pobreza de las últimas tres décadas: $26 \%$.

Salir de la crisis actual involucra un nuevo pacto social, para el cual este libro de Cubillo puede dar muchas luces. Por eso, debería ser un texto obligatorio en la enseñanza secundaria del país y en su difusión deberían utilizarse todas las posibles estrategias. Por fortuna, está escrito de manera de amena y con destreza, lo que hace que pueda ser leído por cualquier audiencia; ese es otro logro más de la destacada académica que lo escribió. 